\title{
Miejsce urodzenia po Zagładzie w poezji Rejzl Żychlińskiej - w stronę innego projektu tożsamościowego*
}

W wywiadzie opublikowanym w piśmie „Wole Oko” Bracha L. Ettinger podkreśla:

Polska dla mojej rodziny była zawsze powiązana ze śmiercią, dramatyczną przeszłością, ale też $\mathrm{z}$ wodą i zielonymi polami, ich miejscem narodzin, dzieciństwem i marzeniami o przyszłości, z całym życiem przed katastrofą. [...] Nie ma dla mnie kwestii powrotu, chyba że powrotu do pewnego „ducha”. [...] Tym, co odziedziczyliśmy, niekoniecznie jest pragnienie powrotu na dawne terytorium. Od II wojny światowej znaczenia słowa „dom” i „wspólnota” przeszło w nas dużą ewolucję ${ }^{1}$.

Z przywołanych fragmentów można wyczytać dwa główne aspekty charakteryzujące żydowskie miejsce urodzenia. W pierwszej części wypowiedzi Ettinger wskazuje na zasadniczą podwójność - a nawet kontaminacyjność - tego miejsca, naznaczonego z jednej strony doświadczeniem Zagłady oraz powojennymi przemieszczeniami determinowanymi poczuciem zagrożenia, strachu czy dojmującą pustką i utratą, a z drugiej odsyłającego do wspomnień dzieciństwa (przywoływanych często w konwencji arkadyjskiej). Druga poruszona przez filozofkę kwestia dotyczy (nie)możności powrotu do miejsca urodzenia po Zagładzie i - co za tym idzie - przewartościowania znaczeń zwyczajowo z powrotem

* Artykuł finansowany ze środków budżetowych na naukę w latach 2016-2020 jako projekt badawczy w ramach programu „Diamentowy Grant”.

${ }^{1}$...Language, a Missing Mamalangue. Z Brachą L. Ettinger rozmawia Monika KęDziora. „Wole Oko. Półrocznik historii sztuki” 2011, nr 1, s. 37, 48. 
powiązanych. Rozpoznania Ettinger wydają się tu kompatybilne z poetyckimi rekontekstualizacjami, jakich pod wpływem tużpowojennych powrotów dokonują żydowscy pisarze tworzący w języku jidysz ${ }^{2}$. Ich utwory pokazują, że konfrontacja $\mathrm{z}$ trudnym dziedzictwem rodzinnych stron nieuchronnie zakłada konieczność zarówno rewizji dotychczasowego stosunku do tego miejsca, jak i ponownego postawienia pytania o własną tożsamość.

W artykule tym interesuje mnie pytanie, w jaki sposób pod wpływem doświadczenia Zagłady dokonuje się reorientacja symbolicznego i znaczeniowego umocowania żydowskiego miejsca urodzenia, a następnie konceptualizacja jego tożsamościowego potencjału. Punktem odniesienia dla tych rozważań będzie poezja Rejzl Żychlińskiej, autorki urodzonej w 1910 roku w Gąbinie, która Zagładę przeżyła na terenie ZSRR (wraz z mężem i synem) ${ }^{4}$. W jej twórczości również tej przedwojennej - istotną rolę odgrywa miejsce urodzenia, a zwłaszcza dom rodzinny. Jego centralną postacią w przedwojennych utworach jest matka, pokazana jako ostoja domowego świata, bohaterka codzienności zmagająca się z trudami samotnego życia (ojciec, który kilkakrotnie opuszczał rodzinę, wyjeżdżając do Ameryki w celach zarobkowych, zostaje w lirykach Żychlińskiej utożsamiony z odległą, obcą krainą). Pod wpływem przeprowadzki do Warszawy w 1936 roku w poezji Żychlińskiej ujawnia się problematyczność opuszczenia miejsca urodzenia oraz poczucia bycia-nie-u-siebie. W wierszu o znamiennym tytule Na obczyźnie, datowanym na 1938 rok, poetka wyznaje: „To nie jest moje okno. / Ta odrobina śniegu nie jest moja. / W obcym domu / czuwam w obcą noc / W obcym kraju / modlę się / do obcego Boga [...] / Tylko ja milczę / Tak jak milczy / Zabłąkany list"5.

2 Temat tużpowojennych powrotów pisarzy żydowskich do miejsc urodzenia rozwijam w tekście: „Czego jeszcze tu szukam w tym miasteczku?”. Powrót do miejsca urodzenia w tużpowojennej literaturze jidysz. W: Sam początek. Lata 1944-1948 w literaturze okresu Polski Ludowej. Red. H. Gosk, B. Karwowska. Warszawa 2017, s. 263-279. Więcej o proponowanej przeze mnie kategorii miejsca urodzenia zob. Miejsce urodzenia a projektowanie tożsamości - przymiarki. „Teksty Drugie” 2019, nr 2, s. 337-352.

3 Tłumaczenia niektórych z przywoływanych przeze mnie utworów Żychlińskiej znajdują się w antologii Magdaleny Ruty (Nie nad rzekami Babilonu. Antologia poezji jidysz w powojennej Polsce. Kraków 2012) oraz w antologii w opracowaniu Karoliny Szymaniak, Joanny Lisek i Belli Szwarcman-Czarnoty (Moja dzika koza. Antologia poetek jidysz. Kraków 2019), niektóre utwory natomiast nie były do tej pory przekładane na język polski. W swojej analizie opieram się na tekstach oryginalnych i podaję własne tłumaczenia dosłowne (jeśli nie zaznaczono inaczej). W szczególnych przypadkach przywołuję cytaty z tekstu jidyszowego, które podaję w wersji oryginalnej, transkrybowanej zgodnie z zasadami fonetyki języka polskiego.

${ }^{4}$ Por. B. Szwarcman-Czarnota: Rejzl z Gąbina. O poezji Rejzl Żychlińskiej. „Etnografia Nowa. Etnografia żydowska do 1945 roku. Powrót do Gąbina" 2015-2016, nr 7-8, s. 139-146. W numerze znalazł się również wybór poezji Żychlińskiej w tłumaczeniu Szwarcman-Czarnoty.

${ }^{5}$ R. Żychlińska: Na obczyźnie. Przeł. B. Szwarcman-Czarnota. W: B. Szwarcman-CzARnota: Rejzl z Gąbina..., s. 151-152. 
W przedmowie do jej debiutanckiego zbioru Lider, opublikowanego w Warszawie w 1936 roku, Icyk Manger pisał o nowej poetce języka jidysz, że jest „więźniarką domowej idylli”. Pomijając tu kwestię typowego dla ówczesnej (zwykle męskiej) recepcji tzw. jidyszowej literatury kobiecej skojarzenia z przestrzenią domową ${ }^{7}$ a biorąc pod uwagę fakt, że miejsce urodzenia stało się podstawą rozproszonej tożsamości Żychlińskiej i źródłem obsesyjnej melancholii, można przyznać, że rozpoznanie Mangera trafnie podsumowuje jej poezję oraz wskazuje na główny problem, któremu bliżej przyjrzę się w niniejszym artykule.

\section{Żydowskie (jidyszowe) miejsce urodzenia}

Żychlińska do końca życia tworzyła w języku jidysz. Język wypowiedzi artystycznej ma tu konkretne znaczenie. David G. Roskies twierdzi, że w badaniach nad literaturą Holokaustu istotne miejsce zajmuje powojenna twórczość w jidysz, gdyż jej dominującym tematem pozostaje doświadczenie Zagłady: „[... ] w jidysz istnieje nieprzerwany, nagromadzony, zróżnicowany, wewnętrznie spójny i ponadnarodowy korpus twórczości na temat Holokaustu"8. Ponadto poezja (czy szerzej - literatura) pisana w jidysz stanowi egzemplaryczny przykład twórczości, która mierzy się z miejscem urodzenia i jego pozagładowym brakiem. Jej wyjątkowość w odniesieniu do konceptualizacji miejsca urodzenia determinuje tworzenie w języku zgładzonego świata, co implikuje zarówno konieczność

${ }^{6}$ I. Manger: Forwort. W: R. Żychlińska: Lider. Warszawa 1936, s. 7. Przed wojną Żychlińska opublikowała jeszcze jeden zbiór poezji - Der regn zignt (Warszawa 1939). Po wojnie zostały wydane jej kolejne tomiki: Cu Lojtere Bregn [„Do jasnych brzegów”]. Łódź 1948; Szwajgndike tirn [„Milczące drzwi”]. Nowy Jork 1962; Harbstike skwern. Lider [„Jesienne skwery. Wiersze”]. Nowy Jork 1969; Di Nowember-Zun. Lider un Dercejlungen [„Listopadowe słońce. Wiersze i opowiadania”]. Paryż 1977; Naje Lider [„Nowe wiersze”]. Tel Awiw 1993. Najbardziej obszerne omówienia twórczości Żychlińskiej przynosi Elvira Groezinger w artykule Rajzel Zychlinski's Poetical Trajectories in the Shadow of the Holocaust. In: Women Writers of Yiddish Literature: Critical Essays. Ed. R. Horowitz. Jefferson, NC 2015, s. 270-293, oraz Karina von TippelsKirCH w monografii „Also das Alphabet vergessen?". Die jiddische Dichterin Rajzel Zychlinski. Marburg 2000. Na temat biografii Żychlińskiej zob. B. Szwarcman-Czarnota: Rejzl z Gąbina..., s. 139-160, lub K. von TipPelskirch: Rajzel Zychlinski. Dostępne w Internecie: https://jwa.org/encyclopedia/article/ Zychlinski-Rajzel [data dostępu: 28.03.2019].

${ }^{7}$ Recepcja (zwykle męska) twórczości Żydówek piszących w jidysz sytuowała je przeważnie w przestrzeni prywatnej, domowej, umniejszając tym samym artystyczną wartość tych dokonań. Więcej na ten temat: J. LiseK: Kol isze - głos kobiet w poezji jidysz (od XVI w. do 1939 r.). Sejny 2018.

${ }^{8}$ D.G. Roskies: Czym jest literatura Holokaustu? Przeł. M. Adamczyk-Garbowska. „Literatura na Świecie" 2005, nr 9-10, s. 239. 
odwołania się do własnych korzeni, jak i przeorientowanie aktu literackiej komunikacji oraz ról jego uczestników: pisarza (kwestii jego powinności), tekstu (pytania o to, co ma być przedmiotem literackiej refleksji) oraz czytelnika (straumatyzowanego doświadczeniami Zagłady). Na problem ten wskazuje $\mathrm{w}$ przedmowie do tużpowojennego zbioru Cu Lojtere Bregn („Do jasnych brzegów”) ${ }^{9}$ sama Żychlińska, pisząc: „Krwawy strumień obmył moją książeczkę, mojego czytelnika i mój dom wyrwany z korzeniami. Mój dom - moja pierwsza poetycka wizja - został starty, tak jak wszystkie nasze domy. Pusty, opustoszały teren" (CLB, s. 4). W obraz miejsca urodzenia po Zagładzie zostaje wpisany koniec żydowskiego świata, którego częścią są tworzący w jidysz autorzy, a wraz z nim okaleczenie języka i kultury jidysz ${ }^{10}$.

Miejsce urodzenia, rozumiane jako konstrukt opisujący momenty zetknięć literatury i geografii, jest bliskie "miejscu autobiograficznemu”, terminowi zaproponowanemu przez Małgorzatę Czermińską. Miejsce autobiograficzne określa literackie wyobrażenie miejsca, które jest konstruowane na podstawie doświadczeń biograficznych danego pisarza. Choć może odnosić się do wyobrażeń wspólnotowych, nie potrzebuje sankcji społecznej, stąd też jego indywidualny charakter. Czermińska wyróżnia miejsce urodzenia jako jedno z miejsc wspominanych, utraconych na przykład w wyniku migracji. Literackie próby opisywania tej utraty korzystają - jak sugeruje badaczka - z zapożyczonej od Adama Mickiewicza strategii przypominania dawnej idylli, mitologizacji lub stereotypizacji ${ }^{11}$.

Konstruowanie miejsca urodzenia w literaturze języka jidysz ma charakter retroaktywny; punktem wyjścia dla tego procesu jest jednak nie tylko doświadczenie utraty, ale także konfrontacja wspomnienia z zastaną rzeczywistością. $\mathrm{W}$ przeciwieństwie do miejsc autobiograficznych koncepcja miejsca urodzenia łączy to, co indywidualne, z tym, co zbiorowe, zakłada ona zmierzenie się ze wspólnotowymi wyobrażeniami współkształtującymi „moje” miejsce urodzenia, odniesienie do sfery intersubiektywnej i do podzielanej przez mieszkańców tożsamości tego miejsca. Symboliczne opanowanie miejsca urodzenia oznacza zarówno usytuowanie go $\mathrm{w}$ sieci różnorakich relacji, jak i świadomość jego wielowarstwowej postaci, w której mieści się również to, co nieświadomie oddziałuje na jego mieszkańców. Wynika z tego, że tworzenie jednostkowej tożsamości stanowi proces negocjowania autonomicznego ,ja” wobec kolektywnego wyobrażenia miejsca, tożsamości zbiorowej, a także wspólnej pamięci, który

9 Zob. R. ŻychlińsKa: Cu Lojtere Bregn... (dalej: CLB).

${ }^{10}$ Por. M. Melchion: Tożsamość żydowska bez jidysz. W: Jidyszland. Polskie przestrzenie. Red. E. Geller, M. Polit. Warszawa 2008, s. 308-311.

${ }^{11}$ Zob. M. Czermińska: Miejsca autobiograficzne. Propozycja w ramach geopoetyki. „Teksty Drugie" 2011, nr 5, s. 190. Por. TAż: Kategoria miejsca autobiograficznego w literaturze doby migracji. W: Narracje migracyjne w literaturze polskiej XX i XXI wieku. Red. H. Gosk. Kraków 2012, s. $50-51$. 
to proces może przyjmować różne formy, na przykład konfliktu, konfrontacji, mediacji czy akceptacji.

Tym, co wreszcie odróżnia miejsce urodzenia od propozycji Czermińskiej, jest też inny rodzaj zależności między pisarzem a jego topograficznym usytuowaniem. Jako dane, a nie wybrane - miejsce urodzenia determinuje w pewnym stopniu usytuowanie podmiotu pod względem geograficznym, historycznym i politycznym, nadaje mu konkretny status społeczny, który z kolei warunkuje otrzymywany na początku kapitał kulturowy. W tym sensie jest ono nieuchronne, a przynajmniej trudniej uwolnić się spod jego wpływu. Miejsce autobiograficzne może być natomiast dowolnie wybraną lokalizacją, w jakiś sposób łączącą się $\mathrm{z}$ biografią autora. Miejsce urodzenia w utworach pisarzy jidyszowych zyskuje ponadto znaczenie dodatkowe - jest ono bowiem ściśle związane $\mathrm{z}$ doświadczeniem Zagłady: śmiercią najbliższych i całych społeczności oraz krajobrazem po katastrofie, gdzie niszczone i zacierane są materialne ślady obecności Żydów. Żydowskie miejsce urodzenia, do którego powracają po wojnie ocalali, zostaje więc naznaczone nieodwracalną i ostateczną pustką.

\section{Chcę jeszcze raz przejść po tej trawie... - powrót}

Żychlińska wraca do swojego rodzinnego miasteczka w 1946 roku. Jej poetycką reakcją na to, co zastała, jest utwór Wiersze o moim domu (opatrzony datą: październik 1946 roku, i poświęcony zgładzonej społeczności żydowskiej Gąbina), który znalazł się w jej pierwszym powojennym tomie Ku jasnym brzegom, opublikowanym w $1948 \mathrm{roku}^{12}$. W tużpowojennej poezji jidyszowej powrót do miejsca urodzenia zakłada wysiłek roz-poznania miejsca urodzenia i zarazem bycia rozpoznanym, rozumiany jako ponowne włączenie do opuszczonej wspólnoty. Roz-poznawanie okolicy odbywa się przede wszystkim poprzez wędrówkę po ziemi urodzenia mającą na celu identyfikowanie charakterystycznych elementów krajobrazowych, pełniących funkcję orientacyjną, a także odtwarzanie "przestrzeni działan"” - somatyczne lub wyobrażeniowe przypominanie sobie praktyk, czynności czy wrażeń kojarzących się z dawnym zamieszkiwaniem przez podmiot danego obszaru. O zapisie wędrówki związanej z roz-poznawaniem w Wierszach o moim domu świadczą nie tylko konkretne czasowniki, ale również zaimki wskazujące, takie jak: tutaj („Ich wil noch a mol do gejn” - Chcę

${ }_{12}$ Wiersz ten został również włączony do powojennego zbioru Szwajgndike tir pod zmienionym tytułem Chcę jeszcze raz przejść po tej trawie.

${ }^{13}$ T. Ingold: Czasowość krajobrazu. Przeł. B. Frydryczak. W: Krajobrazy. Antologia tekstów. Red. B. Frydryczak, D. Angutek. Poznań 2014, s. 141. 
tu jeszcze raz iść, „Wos zuch ich noch do in dem sztetl?” - Czego tu jeszcze szukam w tym miasteczku?) czy oto („Af ot dem sztikl erd / wu s'iz a mol gesztanen majn sztub” - Na tym oto kawałku ziemi, gdzie kiedyś stał mój dom, „Ot zenen zej, / di grine welder - Oto są, / zielone lasy) ${ }^{14}$.

Roz-poznanie miejsca urodzenia wiąże się też z podwójnym postrzeganiem krajobrazu - przywołaniem wspomnienia dawnego wyglądu tego miejsca (w tym przypadku przed katastrofą) i jednocześnie konfrontowaniem przypominanego obrazu z obecnym ukształtowaniem. Porównawcza perspektywa oznacza w przypadku poezji Żychlińskiej łączenie dwóch strategii: niesamowitości, opartej na poczuciu, że miejsce swojskie, znane i bliskie, ujawnia w momencie powrotu swoją obcość i wywołuje lęk ${ }^{15}$, oraz identyczności, a więc akcentowania niezmienności krajobrazu miejsca urodzenia (pomimo katastrofy).

W opisywanym przez Żychlińską Gąbinie nic nie wskazuje na obecność żydowskiej społeczności, a co za tym idzie - nie ma w nim również materialnych śladów istnienia najbliższych autorki i zarazem jej samej. Rodzinny dom, który stanowi centrum poetyckiej wyobraźni Żychlińskiej, przestał istnieć, na co wskazuje jego negatywny opis: „nie ma drzwi”, „nie ma okien, / a słońce / nie będzie już wędrowało od ściany do ściany / od kąta do kąta" (CLB, s. 16). W innym wierszu, Mir lebn wajter („Żyjemy nadal”), znajdujemy następujący fragment: „Prowadzimy nasze dzieci za rączki / mijając zniszczone domy, ruiny ścian, / mijając opustoszałe wyspy martwego dzieciństwa. / Wiatr hula tu wokół, swobodny, beztroski" (CLB, s. 20). Miejsce urodzenia naznacza więc fundamentalny brak, wszystko to, co czyniło je podstawą tożsamości nadanej przez sam akt urodzenia, dawało poczucie stabilności i oparcia, zostało zanegowane. Pustka wpisana w miejsce urodzenia oznacza zarazem brak genealogii oraz materialnego poświadczenia własnego pochodzenia.

To właśnie konfrontacja z pustką miejsca urodzenia, jaką okazuje się powrót, wywołuje poczucie nie-samowitości - splotu tego, co znajome, tutejsze oraz swojskie, i zarazem nieznane, odległe i nieprzyjazne. Opisane za pomocą tej strategii warunki powrotu nie sprzyjają odzyskaniu dawnej więzi z miejscem urodzenia - w zasadzie negują jej możliwość. Autorka, deklarując na początku omawianego utworu powtórzenie wędrówki po ziemi urodzenia, podkreśla bowiem, że „wiatr wieje jej w twarz", a niebo jest ciemnoniebieskie, co konotuje złowrogą aurę. Identyczność krajobrazu paradoksalnie nie przynosi także pocieszenia czy szansy na ponowne oswojenie miejsca urodzenia, wręcz przeciwnie - potęguje poczucie braku i utraty. Przywołajmy dłuższy fragment Wierszy o moim domu:

${ }^{14}$ Do konceptualizacji powrotu do miejsca urodzenia w poezji Żychlińskiej odwołuję się również w tekście: „Czego jeszcze tu szukam w tym miasteczku?”. Powrót do miejsca urodzenia w tużpowojennej literaturze jidysz..., s. 268-270.

${ }^{15}$ Zob. S. Freud: Niesamowite. W: Tenże: Pisma psychologiczne. Przeł. R. Reszke. Warszawa 1997, s. 239. 
Lecą, lecą żółte liście, opowieść błądzi, krąży po drogach, opowieść o ludziach spędzonych na pole gdy padał ulewny deszcz wiosenny.

Trzy tysiące Żydów bez wody, bez chleba, stało przez cztery długie doby.

Dzieci pod gwiazdami płakały jeść.

Od płaczu ich nie pociemniały lasy. Oto one, lasy zielone, lasy mojego domu.

Wysokie, błękitne niebo nie spadło z ogniem z góry... $\mathrm{Na}$ polach pasą się krowy. Pastuch piecze kartofle przy dymie.

CLB, s. 18

Żychlińska podkreśla, że krajobraz jest taki sam, nic się w nim nie zmieniło; życie w jej miejscu urodzenia toczy się nadal według spokojnego rytmu natury. Niemożność pogodzenia domowej okolicy sprzed katastrofy z dramatycznym doświadczeniem pustki poetka wpisuje również w formę swojego wiersza, co pokazują szczególnie dwa pierwsze wersy trzeciej strofy w przywołanym fragmencie. W oryginale brzmią one następująco: „Fun kinderiszn gewejn zajnen tunkeler / niszt geworn di welder arum”. Wprowadzona tu przerzutnia rozbija myśl na dwa opozycyjne człony: pierwszy sugeruje, że tragedia zgładzonej społeczności, którą przywołuje dziecięcy płacz, spowodowała równie dramatyczne zmiany w krajobrazie, podczas gdy drugi przynosi negację naturalnego porządku, w którym każdy czyn powinien pociągać za sobą konkretne konsekwencje. W samej przerzutni zawiera się więc doświadczeniowe rozdarcie - w miejscu urodzenia podmiot nie może odnaleźć ukojenia dla swojego cierpienia, w osobistym cierpieniu pozostaje samotny.

\section{Rzeczywiste i fantomowe}

Ukazana przez poetkę wędrówka do miejsca urodzenia opiera się na kompulsywnych repetycjach, autorka powtarza: „chcę jeszcze raz przejść / po tej trawie / i płakać na tej ziemi”, „odmierzam jeszcze raz nieszczęście / na tym 
kawałku ziemi / gdzie kiedyś stał mój dom” (CLB, s. 16), „czego jeszcze tu szukam w tym miasteczku?” (CLB, s. 18). Powtórzenie czynności i zawarty w nim rodzaj wewnętrznego przymusu, sugerowany przez zwrot „jeszcze raz”, określa przede wszystkim moment formułowania wypowiedzi poetyckiej, którym jest nie tyle sam powrót, ile (ponowne) opuszczenie miasteczka. Celem wędrówki po miejscu urodzenia jest zatem przede wszystkim pożegnanie z nim, co poetka wyraża explicite w ostatniej strofie:

Odchodzę od ciebie, miasteczko.

Twe drogi są takie jak dawniej.

Będziesz nadal świętować jesienie, jarmarki, a rzeka będzie płynąć w dolinie.

CLB, s. 18

Roz-poznanie miejsca urodzenia jako identycznego i zarazem nie-samowitego ukazuje napięcie między próbą zrozumienia siebie w odniesieniu do krajobrazu miejsca urodzenia a poczuciem, że nie ma możliwości udomowienia tej przestrzeni, uczynienia jej ponownie swoją ${ }^{16}$. Poniekąd wiąże się to ze specyfiką samego wędrowania, opisywanego przez Michela de Certeau jako praktyka przestrzenna, która stanowi proces pozbawiania się miejsca i stawania nieobecnym. Intensywne wędrowanie po danym terenie sprawia, że zmienia się ono w doświadczenie braku miejsca ${ }^{17}$. W kontekście Zagłady jego determinantem okazuje się jednak trajektoria powrotu, wskazująca na ruch od życia i światła do śmierci i żałoby - w tej optyce miejsce urodzenia staje się jednocześnie miejscem śmierci ${ }^{18}$. Przejawem życia w żydowskim miejscu urodzenia jest krajobraz i zamieszkujący go obecni mieszkańcy (w Wierszach o moim domu pojawia się postać ospowatej Stasi, która „żyje, chodzi z żołnierzami, / pijana i jak zawsze niedomyta" - CLB, s. 18, czy też pastuch pieczący kartofle w ognisku), ukrytą w nim śmierć ujawnia dopiero przybycie podmiotu. Warto bowiem zaznaczyć, że krajobraz miejsca urodzenia zostaje przez Żychlińską (ale również przez innych autorów żydowskich) uchwycony w teraźniejszości, w chwili powrotu; przeszłość powraca do miejsca wraz z pojawieniem się ocalałego obciążonego traumą Zagłady. Miejsce urodzenia - „kawałek ziemi, na którym kiedyś stał mój dom", jak nazywa je Żychlińska - staje się miarą cierpienia i rozpaczy przy-

${ }^{16}$ Por. R. Sendyka: Miejsca, które strasza (afekty i nie-miejsca pamięci). „Teksty Drugie” 2014, nr 1, s. 90.

${ }_{17}$ Zob. M. de Certeau: Wynaleźć codzienność. Sztuki działania. Przeł. K. Thiel-Jańczuk. Kraków 2008, s. 103.

${ }^{18} \mathrm{Na}$ marginesie warto dodać, że takie odwrócenie kierunku powrotu stanowi też główną ramę filmu Miejsce urodzenia Pawła Łozińskiego, w którym proces dociekania prawdy o losie rodziny Henryka Grynberga przyjmuje formę katabazy - poruszania się coraz niżej, w kierunku wertykalnym, przejścia od świata żywych do świata zmarłych, którego punktem kulminacyjnym jest zejście do wykopanego grobu ojca. 
bywającego podmiotu, który okazuje się jedynym gwarantem pamięci. To jego obecność narusza spokojny i niezmienny rytm okolicy, przełamuje jej dotkliwą identyczność nierespektującą Zagłady, jaka się w niej dokonała:

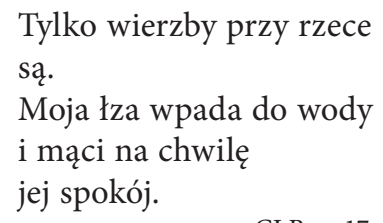

Podmiot inicjuje rytuał żałobny, w ramach którego przełamanie kryzysu i opanowanie afektów związanych z utratą dokonuje się „,w performatywnym akcie elegijnym, w którym opłakujący skupia się na cierpieniu i wspominaniu, tym samym odcinając się od świata zewnętrznego"19. W wierszu Żychlińskiej płacz byłby zatem reakcją na brak własnego miejsca urodzenia, ale także próbą nawiązania z nim łączności, ponownego do niego zbliżenia - jedynym krajobrazowym elementem, który nadal istnieje, są wszak wierzby, symbolicznie konotujące płacz. Dopełnieniem żałoby jest rozluźnienie więzi z utraconym obiektem i ostatecznie jej zerwanie. Żałobny rytuał, jaki zdaje się sugerować w Wierszach o moim domu Żychlińska, nie dotyczy tylko jej samej, ale ma zyskać wymiar wspólnotowy - aby można było przepracować utratę, powinna w nim uczestniczyć cała okolica miejsca urodzenia. Tymczasem - jak pokazuje autorka - zgładzenie społeczności żydowskiej i brak miejsca urodzenia (z jej perspektywy) nie są postrzegane przez obecnych (polskich) mieszkańców w takich samych kategoriach (a więc utraty czy braku). Na tej niezgodności punktów widzenia i przypisaniu miejscu urodzenia innych znaczeń zasadza się podstawowy paradoks tej kategorii w wariancie żydowskim. Utrata rodzinnego miasta i ostatecznie niemożność powrotu wynikają przede wszystkim z poczucia obcości powracającego podmiotu, wykluczenia $\mathrm{z}$ dawnej wspólnoty oraz samotności - nic i nikt w okolicy go nie zauważa ani już nie pamięta. W innym utworze z tomu „Do jasnych brzegów”, zatytułowanym A sztikl erd („Kawałek ziemi"), Żychlińska zapisuje podobnie gorzką obserwację:

Kupcie, kupcie, drodzy sąsiedzi, kupcie ten kawałek ziemi. Tanio, pół darmo.

Zbudujecie tu sobie dom, wykopiecie studnię i posadzicie ogród pod oknem.

${ }^{19}$ K. Bojarska: Żałoba. W: Modi memorandi. Leksykon kultury pamięci. Red. M. SARYusz-Wolska, R. Traba. Współpraca J. Kalicka. Warszawa 2014, s. 561. 
Nie będą was tutaj straszyć widma.

Mama moja nie wróci z komory gazowej.

Ani jej wnuki.

I ja także już tu nie przyjdę

Ze swymi łzami.

CLB, s. 21

W ostatniej strofie Wierszy o moim domu, w której poetka bezpośrednio zwraca się do miasteczka, przewiduje, co nastąpi po jej odejściu: „będziesz nadal świętować jesienie, jarmarki, / a rzeka będzie płynąć w dolinie”. Kończąca utwór wizja miejsca urodzenia skierowana w przyszłość wskazuje nie tyle na zerwanie więzi podmiotu z miejscem, gdzie się urodził (ta więź w przypadku Żychlińskiej nie zostanie ostatecznie zerwana), ile na oderwanie dawnego miejsca urodzenia, przyjmującego postać wyobrażeniową i fantomową, od tego realnego i faktycznego, z którym powracający podmiot nie odnajduje już żadnego związku. Idąc dalej - zalążki nowej tożsamości tworzą się już po stronie straumatyzowanego podmiotu, jego pamięci i doświadczenia, z których utkany jest fantom miejsca urodzenia. Jak pisze Katarzyna Bojarska, asymboliczne treści w fantomowej formie zostają inkorporowane do wnętrza podmiotu i złożone w tzw. psychicznej krypcie, niezintegrowanej z całością jego życia psychicznego. Obcość fantomu sprawia, że może on wyłaniać się jako widmo przeszłości nawiedzające teraźniejszośćc ${ }^{20}$.

W Wierszach o moim domu - w każdej z trzech tworzących ten utwór części rzeczywiste miejsce urodzenia jest kontrapunktowane tym fantomowym. W tym współistnieniu obu wymiarów żydowskiego miejsca urodzenia dostrzegam jego kontaminacyjny charakter, łączący sprzeczne treściowo komponenty. Opisowi zastanego, teraźniejszego krajobrazu w poszczególnych częściach towarzyszą przywołane przez podmiot wspomnienie z dzieciństwa („mama - / nie wróci już do domu / zaśnieżona, / z błękitnym dzbanem mleka w dłoni / i błękitnym światłem w oczach” - CLB, s. 16), unosząca się nad okolicą „opowieść o ludziach spędzonych na pole", która pozwala Żychlińskiej przywrócić miejscu urodzenia pamięć o zgładzonych, oraz wyobrażenie śmierci żydowskiego chłopca, której świadkinią była autorka.

Poezja Żychlińskiej sugeruje więc, że żydowskie miejsce urodzenia jest (przywołując terminologię zaproponowaną przez Marca Augé) z jednej strony formą „miejsca antropologicznego”, będącego „wyobrażeniem, częściowo zmaterializowanym, które tworzą ludzie je zamieszkujący na temat swojej relacji do terytorium, do swoich bliskich, i do innych" ${ }^{21}$, umożliwiającego budowanie spójnej, ciągłej i stabilnej tożsamości, a z drugiej - „nie-miejscem”, pozbawioną

20 Por. tamże.

${ }^{21}$ M. Augé: Nie-miejsca. Wprowadzenie do antropologii hipernowoczesności. Przeł. R. CHyMKOWski. Warszawa 2010, s. 37. 
tożsamościowych atrybutów przestrzenią tranzytową nakierowaną na ruch i przepływ. Ten kontaminacyjny (schizofreniczny?) splot można inaczej opisać, odwołując się - za Michaliną Kmiecik - do potencjałów topicznego i atopicznego. Pierwszy przejawiają miejsca antropologiczne, które „nawet jeśli nie są przejrzyste i wymagają podjęcia pracy pamięci, zawsze zmierzają do ukonstytuowania sensu, odkrycia prawdy o własnej tożsamości”. Atopiczność miejsca natomiast kwestionuje jego formatywność, sprawia, że miejsca „wymykają się człowiekowi, nie sprzyjają stworzeniu stabilnego samookreślenia"22.

\section{Tożsamość rozproszona}

Niemożność odzyskania dawnego miejsca urodzenia podaje w wątpliwość dotychczasową tożsamość, nadaną przez akt narodzin, i wymaga ukonstytuowania jej na nowo. Projekty tożsamościowe jidyszowych pisarzy, powracających po wojnie z ZSRR, zdają się wpisywać $\mathrm{w}$ dialektykę końca i początku oraz eksponować zasadniczą podwójność między zmaganiem się z traumatycznym doświadczeniem Zagłady a kształtowaniem nowego porządku i świata, którego model proponował komunizm ${ }^{23}$. Tę podwójność zaznacza w swojej przedmowie do zbioru „Do jasnych brzegów” Rejzl Żychlińska:

W niniejszym tomiku chcę przynieść nie tylko echo zagłady, wędrowania i błądzenia, ale również promień nadziei, który przyniosłam z sobą z gościnnej rosyjskiej ziemi, i który podnosi się na brzegach naszego obiecanego kraju ${ }^{24}$.

Większość jidyszowych pisarzy próbuje ustalić swoją pozycję wobec zgładzonej społeczności żydowskiej - gest ten determinuje imperatyw etyczny, próba zadośćuczynienia, upamiętnienia lub przepracowania poczucia winy z powodu własnego ocalenia. Na sytuowanie siebie wobec ofiar wskazują między innymi dedykacje publikowanych tuż po wojnie tomów wierszy, poświęconych pamięci zgładzonych wspólnot (na przykład u Binema Hellera, Rejzl Żychlińskiej, Men-

${ }^{22}$ M. KMIeciк: Oblicza miejsca. Topiczne i atopiczne wyobrażenia przestrzeni w poezji Juliana Przybosia. Kraków 2013, s. 17.

${ }^{23}$ Większość pisarzy żydowskich ocalałych na terenie ZSRR miała lewicowe poglądy, część z nich była związana z komunizmem jeszcze przed wybuchem wojny (np. Binem Heller). Żychlińska była poetką, która raczej unikała deklaracji politycznych, dlatego też wątek ten przywołuję jedynie kontekstowo. Więcej na temat związków żydowskich pisarzy z komunizmem zob. M. Ruta: Tożsamość żydowskiego komunisty. W: TAŻ: Bez Żydów? Literatura jidysz w PRL o Zagładzie, Polsce i komunizmie. Kraków-Budapeszt 2012, s. 257-324. Por. J. Nalewajko-Kulikov: Obywatel Jidyszlandu. Rzecz o żydowskich komunistach w Polsce. Warszawa 2009.

${ }^{24}$ R. Żychlińska: [Przedmowa]. W: Taż: Cu Lojtere Bregn..., s. 4. 
dla Mana). Próba restytuowania dawnego świata w poezji jidyszowych autorów, wracających do swoich miejsc urodzenia, może być motywowana doświadczeniem ocalałych na Wschodzie jako „ofiar-świadków zastępczych”25. Magdalena Ruta - powołując się na psychologiczne opisy syndromu PTSD - stwierdza, że jidyszowi twórcy, którzy przeżyli Zagładę na terenie ZSRR, nie tyle opisują swoje doświadczenia wojenne, ile wyobrażają sobie śmierć bliskich, próbując nadać sens temu, co spotkało zamordowanych; to los rodziny staje się konstytutywnym doświadczeniem ich tożsamości ${ }^{26}$.

W ukazane przez Żychlińską doświadczenie miejsca urodzenia zostaje wpisana rozdzierająca podwójność - z jednej strony bolesna świadomość utraty, a $\mathrm{z}$ drugiej - afektywnie motywowana potrzeba poszukiwania łączności z tamtym światem, odzyskania więzi z tamtymi ludźmi. W procesie ustalania nowej tożsamości poetka opiera się na wyobrażeniu śmierci społeczności żydowskiej:

Kto mnie woła na tym polu

Kto mnie tu zna, kto zna moje imię?

Krzew płonie na polu -

Lejbuś krzyczy z płomieni.

Zdejmuję buty i podchodzę

do małego synka mojego sąsiada;

Jego rączki są już czarne,

tylko oczy są jeszcze otwarte.

CLB, s. 18

Miejsce śmierci jest restytuowane w formie sakralizowanej, staje się miejscem świętym, o czym świadczy trawestacja biblijnego motywu gorejącego krzewu. Podmiot przyjmuje natomiast rolę Mojżesza, który przed wejściem w sferę sacrum na górze Synaj zdejmuje buty. Żychlińska projektuje scenę przybliżenia się do Zagłady, której egzemplifikacją jest śmierć żydowskiego chłopca. Wyobrażenie to poprzedza strofa, w której autorka (zniecierpliwiona? poirytowana?) zadaje sobie pytanie: „Czego tu jeszcze szukam w tym miasteczku?”. Pojawia się ono już po rozpoznaniu pustki miejsca urodzenia oraz po przywołaniu losu miejscowej społeczności żydowskiej („opowieść błądzi, krąży po drogach, / opowieść o ludziach spędzonych na pole”). Pierwsze dwie części Wierszy o moim domu ukazują przestrzenny i topograficzny wymiar miejsca urodzenia, a doświadczenie Zagłady pojawia się w nich w sposób zapośredniczony (przez krajobraz i opowieść/przekazaną autorce relację); w trzeciej natomiast następuje próba zaaranżowania bezpośredniego spotkania $\mathrm{z}$ ofiarami. Skoro celem powrotu okazuje się opuszczenie miejsca urodzenia, to jego warunkiem byłoby pożegnanie zmarłych, dawnych mieszkańców.

\footnotetext{
${ }^{25}$ Zob. M. Ruta: Odpowiedź na Zagładę. W: TAż: Bez Żydów?..., s. 41.

26 Por. tamże, s. 40.
} 
Poprzez wyobrażenie cierpienia i zagłady żydowskiej wspólnoty, do której poetka należała, podejmuje ona próbę zbudowania afektywnej łączności z tymi, którzy zginęli, mając zarazem świadomość niepowodzenia tego projektu. Ukazuje to sugestywnie w wierszu Moja siostra Chana:

Na chłodnej chmurze, na błękitnym okręcie płynie moja siostra Chana.

Wołam ją całymi dniami:

- Siostro moja, poczekaj -

Ona nie odpowiada -

i odpływa daleko

CLB, s. 10

Patrzenie na traumatyczne wydarzenie, które sytuuje poetkę zarazem wewnątrz i na zewnątrz całego zajścia, akcentuje rozpaczliwą bezradność oraz świadomość nieodwracalności Zagłady. Konfrontacja ze spojrzeniem ofiary implikuje także poczucie winy i wstydu z powodu własnego ocalenia. Zdaniem Ruth Leys, „wstyd jest emocją kierowaną przez spojrzenie, logika wstydu natomiast to scena wystawienia (nawet wówczas, gdy scena jest wyłącznie wyobrażona, a obserwator nie staje się zewnętrznym widzem, ale uwewnętrznionym innym)" 27 . Wstyd ma wymiar introspektywny i tożsamościotwórczy, łączy się bowiem z poczuciem tego, kim się jest (w przeciwieństwie do winy, związanej $\mathrm{z}$ działaniem lub jego brakiem $)^{28}$. Tożsamość, opierając się na wstydzie z powodu bycia ocalonym, wyraża się w trwaniu pomiędzy życiem a śmiercią, w łączności ze śmiercią bliskich przez samą możliwość własnej śmierci. Poetka ujawnia to tożsamościowe rozdarcie w wierszu Moje żydowskie oczy:

Grób musiałam wykopać

gołymi rękami sama.

Tylko głowa mi z grobu wystaje

przeklęta roślina, która nie chce umrzeć.

CLB, s. 5-6

Jill Bennett podkreśla, że spojrzenie ma charakter nie tyle dystansujący, ile doznaniowy, angażujący i aktywizujący. Zastanawiając się nad działaniem

${ }^{27}$ R. Leys: Wstyd współcześnie. Przeł. A. Kowalcze-Pawlik, T. Bilczewski. W: Afektywne historie i polityki pamięci. Red. E. Wichrowska, A. Szczepan-Wojnarska, R. Sendyka, R. Nycz. Warszawa 2015, s. 354. Leys zauważa, że w teoretycznych ujęciach PTSD wstyd zajmuje dziś miejsce zarezerwowane dotychczas dla winy ocalałych. Choć w przeszłości badacze skłaniali się ku stanowisku zakładającemu, że ocalali z traumy doświadczali winy ze względu na sam fakt przetrwania lub też nie rozróżniali wstydu i winy, obecny kompromis uznaje wstyd za emocję równie istotną dla zespołu stresu pourazowego.

${ }^{28}$ Por. tamże, s. 360. 
obrazów, badaczka stwierdza, że „zapośredniczony w obrazie przekaz cierpienia możliwy jest jedynie w stopniu, w jakim obrazy wykazują zdolność odniesienia się do własnej cielesnej pamięci oglądającego; dotykania odbiorcy, który nie tyle po prostu widzi zdarzenie, ile je odczuwa, wciągnięty w obraz dzięki procesowi afektywnego zarażenia"29. Ukazując wyobrażone cierpienia własnej wspólnoty, Żychlińska dokonuje niejako aktu włączenia siebie w los zgładzonych. Poetka przyjmuje strategię „wczuwania się współczującej wyobraźni” ${ }^{30}$ i tym samym powołuje wspólnotę afektywną, zakładającą zbliżenie współ-czujące oraz empatyczną współ-obecność. Wspólnotowe więzi spaja doświadczenie afektywne, które nie daje się wyrazić wprost, gdyż zakłada inny rodzaj poznania, opartego na odczuwaniu, somatycznym poruszeniu i intensywności; jako takie wyprzedza poznanie rozumowe.

W jaki sposób afektywne włączenie siebie we wspólnotę zmarłych determinuje tożsamość? Jaki projekt tożsamościowy może wyłonić się ze sprzężenia konkretnego miejsca urodzenia (Gąbina) z jego fantomowym wyobrażeniem? Elvira Groezinger podpowiada, że Żychlińska powołuje w swojej poezji figurę nowego „Żyda tułacza”, pozbawionego korzeni i funkcjonującego w cieniu Zagłady $^{31}$. Tułactwo - wpisane wszak w tradycję żydowską - stawałoby się tu tożsamościową udręką; projekt tożsamości pozbawiony miejsca urodzenia (w sytuacji przemocy czy przymusowej migracji) wyznacza bowiem brak zakorzenienia, niemożność odnalezienia ponownie swojego miejsca, a także skłonność do tworzenia „retrotopii”, które Zygmunt Bauman nazywa „wizją osadzoną w utraconej/skradzionej/porzuconej, ale nieumarłej przeszłości, zamiast przywiązania do tego, co dopiero ma się narodzić, a więc do przyszłości jeszcze niezaistniałej”, przywiązaniem do „stałego gruntu, który, jak można żywić nadzieję, zagwarantuje akceptowalne minimum stabilności”32. Charakterystyczne dla żydowskiego miejsca urodzenia po Zagładzie jest bowiem uwikłanie w przeszłość poprzez poczucie bycia-nie-u-siebie i związany z nim strach przed ponowną utratą „stałego gruntu”. Lęk ten towarzyszy również poetyckim ekspresjom Żychlińskiej, na przykład w wierszu Di erd-citernisz in jor 1989 („Trzęsienie ziemi w 1989 roku”), w którym pisze: „Ściany mojego domu trzęsą się / a ja wraz z nimi”33.

${ }^{29}$ J. Bennett: Wnętrza, zewnętrza: trauma, afekt i sztuka. Przeł. A. Kowalcze-Pawlik, T. Bilczewski. W: Pamięć i afekty. Red. Z. Budrewicz, R. Sendyka, R. Nycz. Warszawa 2014, s. $165-166$.

${ }^{30}$ J. Hensel: Ofiary i świadkowie. Wiersze czasu wojny jako źródło wiedzy o Zagładzie. W: Literatura polska wobec Zagłady. Red. A. Brodzka-Wald, D. KrawczyńsKa, J. Leociak. Warszawa 2000, s. 64.

${ }^{31}$ Zob. E. Groezinger: Rajzel Zychlinski's Poetical Trajectories..., s. 271.

32 Z. Bauman: Retrotopia. Jak rządzi nami przeszłość. Przeł. K. LebeK. Warszawa 2018, s. 13, $18-19$.

${ }^{33}$ R. ŻychlińsKa: Naje Lider..., s. 24. 
Fantomowy wymiar miejsca urodzenia wskazuje na odczuwanie bólu w miejscu po amputowanej tożsamości - tej pierwotnej, nadanej w momencie narodzin. W takiej postaci miejsce urodzenia jako „nic, które boli”, wchodzi w związek z melancholią. „[...] dotknięty melancholią nie wie, jakiej doznał straty; często potrafi ją ukonkretnić: czyjeś odejście, czyjaś śmierć, upadek ideału. Nie wie natomiast, nawet gdy zna obiekt straty, co w nim utracił i jego praca żałoby nie może się dokonać"34. Jak pisał Tadeusz Sławek:

Zakorzenienie to forma zrozumienia człowieka jako bytu głęboko relacyjnego, przy czym jedynie część owych relacji bywa przez nas jasno uświadamiana; zakorzenienie, o ile ma spełnić swoją rolę, z konieczności wprowadza nas w ciemny świat tego, co podziemne, lecz co wcale nie jest mniej aktywne. Jesteśmy nawiedzani przez to, w czym się zakorzeniamy, przesiąkamy jego treściami ${ }^{35}$.

„Nawiedzanie” przez miejsce urodzenia jest jedną z dominujących optyk powojennej poezji Żychlińskiej. Podejmując próbę przepisania na nowo swojego miejsca urodzenia i - co za tym idzie - stworzenia innego mitu początku, w utworze Gebojrn hot mich der wint („Urodził mnie wiatr”) z tomu Szwajgndike tir („Milczące drzwi”) buduje ona następujący obraz: „Urodził mnie wiatr, / karmiła góra, / księżyc był moją kołyską, / stare drzewa kołysały mnie do snu, / a mama była snem"36. Przebłyski traumatycznych wspomnień ukazuje również strategia palimpsestowego postrzegania krajobrazu, na który nakłada się wizja zmarłych, jak w liryku Co tam płynie na rzece Hudson:
Co tam płynie na rzece Hudson
$\mathrm{W}$ czerwonej poświacie?
Kto tam krzyczy - ratuj,
Idziemy na dno -
To moi zmarli,
Spaleni,
Którzy jeszcze raz idą na dno -
$\mathrm{W}$ mej pamięci. ${ }^{37}$

Żychlińska wszędzie czuła się samotna i obca, w Stanach Zjednoczonych często zmieniała miejsce zamieszkania. Dręczyło ją poczucie winy z powodu opuszczenia bliskich, zwłaszcza matki. Traktowała ona swoje ocalenie jako powtórzenie losu znienawidzonego ojca, który przed wojną zostawił rodzinę i wyjechał do Ame-

${ }^{34}$ M. BieńCzyk: Melancholia. O tych, co nigdy nie odnajda straty. Warszawa 2000, s. 16.

35 T. SŁAWeK: Gdzie? Rozważania oikologiczne. „Anthropos?” 2011, nr 16-17, s. 1. Por. Oikologia. Nauka o domu. Red. T. SŁAWeK, A. Kunce, Z. KadŁubeK. Katowice 2013.

${ }^{36}$ R. ŻyChlińsKa: Szwajgndike tirn..., s. 53.

${ }^{37}$ R. Żychlińska: Co tam plynie na rzece Hudson. Przeł. B. Szwarcman-Czarnota. W: Moja dzika koza..., s. 474. 
ryki ${ }^{38}$. Tożsamość po utracie więzi z miejscem urodzenia staje się „tożsamością rozproszoną", nie można jej ponownie scalić. Poetka zmarła 13 czerwca 2001 roku, zgodnie z jej życzeniem prochy rozsypano nad morzem w dniu jej dziewięćdziesiątych pierwszych urodzin (27 czerwca). Ten symboliczny gest potwierdza, że poczucie bycia-nie-u-siebie stało się wyznacznikiem jej pozagładowej tożsamości. Miejsce, z którym związał ją akt urodzenia, stało się dla niej przeklęte - po śmierci pozostała więc $\mathrm{z}$ wyboru bezdomna, bez konkretnego miejsca.

\section{Zakończenie}

Poezja Rejzl Żychlińskiej pokazuje, że powrót prototypowy, który jest podejmowany $\mathrm{z}$ intencją pozostania $\mathrm{w}$ danym miejscu, nie może się $\mathrm{w}$ takiej postaci dokonać, staje się „powrotem niemożliwym”. Zamiast obietnicy ponownego zamieszkania i stabilności tużpowojenny powrót uświadamia utratę rodziny i wspólnoty oraz brak miejsca urodzenia. Jego wyobrażenie jako centrum ustalonych wartości, symbolu bezpieczeństwa i trwałości, umożliwiającego realizację prymarnej ludzkiej potrzeby przynależności, zostaje przez Żychlińską odrzucone. Staje się ono tym samym nie-miejscem, fantomem, który - nawiedzając teraźniejszość - wikła podmiot w przeszłość.

Powrót do żydowskiego miejsca urodzenia wiąże się z przymusem tułaczki. Bycie pozbawionym tego miejsca nie generuje jednak nomadyczności w takim znaczeniu, jakie nadała jej Rosi Braidotti ${ }^{39}$. Podmiot nomadyczny buduje swoją spójność dzięki rytmicznym przemieszczeniom, pozostawaniu w ciągłym ruchu, który nie jest ograniczony przestrzennie - nie ma ani określonego z góry miejsca docelowego swojej wędrówki, ani utraconego kraju ojczystego. Nomadyczność jest stanem przyjmowanym pozytywnie i realizującym się w sytuacji swego rodzaju komfortu (psychicznego, fizycznego czy materialnego). Kategoria miejsca urodzenia ujawnia niewystarczalność tych rozpoznań do opisu przemieszczeń traumatycznych, determinowanych poczuciem zagrożenia, strachu czy doświadczeniem utraty, których efektem są tożsamości rozproszone, pozbawione przestrzennego oparcia, ale zarazem uwikłane w kontaminacyjny splot konkretnego, rzeczywistego i zarazem wyobrażeniowego miejsca urodzenia.

Żychlińska wyjechała z Polski w 1948 roku $^{40}$. W wierszu Kawałek ziemi autorka pisze:

${ }^{38}$ Por. E. Groezinger: Rajzel Zychlinski's Poetical Trajectories..., s. 280.

39 Zob. R. Braidotti: Poprzez nomadyzm. Przeł. A. Derra. „Teksty Drugie” 2007, nr 6, s. 117-118.

${ }^{40} \mathrm{Na}$ temat motywacji tużpowojennych emigracji z Polski zob. N. CoHen: Przyczyny emigracji pisarzy żydowskich $z$ Polski w latach 1945-1948. W: Nusech Pojln. Studia z dziejów kultury jidysz w powojennej Polsce. Red. M. Ruta. Kraków-Budapeszt 2008, s. 231-246. 
Kupcie, kupcie, drodzy sąsiedzi, kupcie ten kawałek ziemi. Tanio, pół darmo.

Zbudujecie tu sobie dom,

Wykopiecie studnię,

I posadzicie kwiaty pod oknem. [...]

Zabieram stąd tylko kamień -

Stąpała po nim noga mojej mamy

W obce, bezdomne noce

Będzie mi poduszką pod głowę [...]

Miejsca, gdzie stała moja kołyska,

Nie pokażę mojemu dziecku.

CLB, s. 21

Opuszczenie miejsca urodzenia niesie za sobą obietnicę uwolnienia się od traumatycznych wspomnień, które to miejsce ewokuje; stanowi również akt symbolicznego pożegnania dawnego (przedwojennego) świata, zamknięcia pewnego etapu życia, a wyznaczenia nowego początku. Konieczność odejścia z miejsca urodzenia poetka ukazuje w dramatyczny i gorzki sposób. Jej radykalny gest wyzbycia się wszelkich praw do tego miejsca nie może jednak zapewnić całkowitego odcięcia się od balastu traumatycznej przeszłości.

\section{Bibliografia}

Augé M.: Nie-miejsca. Wprowadzenie do antropologii hipernowoczesności. Przeł. R. Снумкошsкi. Warszawa 2010.

Bauman Z.: Retrotopia. Jak rządzi nami przeszłość. Przeł. K. LebeK. Warszawa 2018.

Bennett J.: Wnętrza, zewnętrza: trauma, afekt i sztuka. Przeł. A. Kowalcze-Pawlik,

T. Bilczewski. W: Pamięć i afekty. Red. Z. Budrewicz, R. Sendyka, R. Nycz. Warszawa 2014, s. 145-179.

BieńCZy K M.: Melancholia. O tych, co nigdy nie odnajda straty. Warszawa 2000.

Bojarska K.: Żałoba. W: Modi memorandi. Leksykon kultury pamięci. Red. M. SARYusz-Wolska, R. Traba. Współpraca J. KalickA. Warszawa 2014, s. 561-562.

Braidotti R.: Poprzez nomadyzm. Przeł. A. Derra. „Teksty Drugie” 2007, nr 6, s. $107-127$.

Certeau M. De: Wynaleźć codzienność. Sztuki działania. Przeł. K. Thiel-Jańczuk. Kraków 2008.

Cohen N.: Przyczyny emigracji pisarzy żydowskich z Polski w latach 1945-1948. W: Nusech Pojln. Studia $z$ dziejów kultury jidysz w powojennej Polsce. Red. M. Ruta. Kraków-Budapeszt 2008, s. 231-246. 
Czermińska M.: Miejsca autobiograficzne. Propozycja $w$ ramach geopoetyki. „Teksty Drugie" 2011, nr 5, s. 183-200.

Freud S.: Niesamowite. W: S. Freud: Pisma psychologiczne. Przeł. R. Reszke. Warszawa 1997, s. 235-262.

Groezinger E.: Rajzel Zychlinski's Poetical Trajectories in the Shadow of the Holocaust. In: Women Writers of Yiddish Literature: Critical Essays. Ed. R. Horowitz. Jefferson, NC 2015, s. 270-293.

Hensel J.: Ofiary i świadkowie. Wiersze czasu wojny jako źródło wiedzy o Zagładzie. W: Literatura polska wobec Zagłady. Red. A. BrodzKa-WALd, D. KrawCZyŃsKa, J. LeOciak. Warszawa 2000, s. 51-64.

Ingold T.: Czasowość krajobrazu. Przeł. B. Frydryczak. W: Krajobrazy. Antologia tekstów. Red. B. Frydryczak, D. Angutek. Poznań 2014, s. 141-164.

Кміесік M.: Oblicza miejsca. Topiczne i atopiczne wyobrażenia przestrzeni w poezji Juliana Przybosia. Kraków 2013.

Koprowska K.: „Czego jeszcze tu szukam w tym miasteczku?”. Powrót do miejsca urodzenia $w$ tużpowojennej literaturze jidysz. W: Sam początek. Lata 1944-1948 w literaturze okresu Polski Ludowej. Red. H. Gosk, B. KarwowsKa. Warszawa 2017, s. $263-279$.

Koprowska K.: Miejsce urodzenia a projektowanie tożsamości - przymiarki. „Teksty Drugie" 2019, nr 2, s. 337-352.

...Language, a Missing Mamalangue. Z Brachą L. Ettinger rozmawia Monika KęDZIora. „Wole Oko. Półrocznik historii sztuki” 2011, nr 1, s. 31-48.

Leys R.: Wstyd współcześnie. Przeł. A. Kowalcze-Pawlik, T. Bilczewski. W: Afektywne historie i polityki pamięci. Red. E. Wichrowska, A. Szczepan-Wojnarska, R. Sendy Ka, R. Nycz. Warszawa 2015, s. 349-401.

LiseK J.: Kol isze - głos kobiet w poezji jidysz (od XVI w. do 1939 r.). Sejny 2018.

MANGer I.: Forwort. W: R. ŻychlińsKa: Lider. Warszawa 1936, s. 3-5.

Melchior M.: Tożsamość żydowska bez jidysz. W: Jidyszland. Polskie przestrzenie. Red. E. Geller, M. Polit. Warszawa 2008, s. 304-320.

Moja dzika koza. Antologia poetek jidysz. Wybór i oprac. K. Szymaniak, J. Lisek, B. Szwarcman-Czarnota. Kraków 2019.

Nie nad rzekami Babilonu. Antologia poezji jidysz w powojennej Polsce. Przeł., red. oraz słowo wstępne M. Ruta. Kraków 2012.

Roskies D.G.: Czym jest literatura Holokaustu? Przeł. M. Adamczyk-Garbowska. „Literatura na Świecie” 2005, nr 9-10, s. 225-249.

Ruta M.: Bez Żydów? Literatura jidysz w PRL o Zagładzie, Polsce i komunizmie. Kraków-Budapeszt 2012.

SENDYKA R.: Miejsca, które straszą (afekty i nie-miejsca pamięci). „Teksty Drugie” 2014, nr 1, s. 84-102.

SŁawek T.: Gdzie? Rozważania oikologiczne. „Anthropos?” 2011, nr 16-17, s. 1-22.

Szwarcman-Czarnota B.: Rejzl z Gąbina. O poezji Rejzl Żychlińskiej. „Etnografia Nowa. Etnografia żydowska do 1945 roku. Powrót do Gąbina” 2015-2016, nr 7-8, s. $139-146$.

Tippelskirch K. von: „Also das Alphabet vergessen?“. Die jiddische Dichterin Rajzel Zychlinski. Marburg 2000. 
Tippelskirch K. von: Rajzel Zychlinski. Dostępne w Internecie: https://jwa.org/encyclo pedia/article/Zychlinski-Rajzel [data dostępu: 28.03.2019].

ŻyCHLińska R.: Cu Lojtere Bregn [„Do jasnych brzegów”]. Łódź 1948.

ŻyCHLIŃsKa R.: Lider [„Wiersze”]. Warszawa 1936.

Żychlińska R.: Naje Lider [„Nowe wiersze”]. Tel Awiw 1993.

Żychlińska R.: Szwajgndike tirn [„Milczące drzwi”]. Nowy Jork 1962.

Karolina Koprowska

Birthplace after the Shoah in Rajzel Żychlińsky’s Poetry Towards a Different Project of Identity

Summary

This article aims at exploring how the experience of the Shoah reorients a Jewish birthplace with regard to its symbolic and signifying potential, and, thereafter, conceptualises its impact on the identity. Precisely, this text attempts to describe and define the specificity of a birthplace after the Shoah, relying on Rajzel Żychlińsky's poetry, still a marginal author writing in Yiddish. As it is shown, birthplaces depend on the duality which resurfaces at the precise moment of a homecoming: they are both spectral and real; this last fact is analysed in the text along with the project of dispersed identity, which the aforementioned binary inaugurates.

Key words: birthplace, identity, Yiddish, Rajzel Żychlińsky, Holocaust 